British Journal of Education, Society \&
Behavioural Science
$18(3):$ 1-9, 2016, Article no.BJESBS.28404
ISSN: 2278-0998
SCIENCEDOMAIN international
www.Sciencedomain.org

\title{
Problems of English Speaking Skill that University Students Encounter from Their Perspectives
}

\author{
Atallah A. Al-Roud ${ }^{1 *}$ \\ ${ }^{1}$ Department of Curricula and Instruction, Faculty of Educational Sciences, Tafila Technical University \\ (TTU), Tafila, Jordan.
}

Author's contribution

The sole author designed, analyzed and interpreted and prepared the manuscript.

Article Information

DOI: 10.9734/BJESBS/2016/28404

Editor(s):

(1) Eleni Griva, University of Western Macedonia, Greece.

Reviewers:

(1) Zuraina Ali, University Malaysia Pahang, Malaysia.

(2) M. Rajendran, SRM University, India.

(3) Ibrahim El-Zraigat, University of Jordan, Jordan.

(4) Azman Bin Che Mat, UiTM Terengganu, Malaysia.

Complete Peer review History: http://www.sciencedomain.org/review-history/16679

Original Research Article

Received $18^{\text {th }}$ July 2016

Accepted $8^{\text {th }}$ September 2016

Published 26 $6^{\text {th }}$ October 2016

\begin{abstract}
A language is a group of skills which ultimately lead to a communication between individuals. Speaking skill is considered as the most important means of communication. For this reason the study aims at finding out the problems that the students of southern region universities in Jordan encounter in English speaking skill. The population of the study consists of the students of Mu'ta university, Al-Husein Bin Talal university, and Tafila Technical university. The sample consists of (239) male and female students. The instrument includes 27 items divided into 4 domains. The results indicated that there are statistically significant differences to the variable of university for all the domains of speaking problems. Those differences were in favor of Tafila Technical University. The results also indicated that there are statistically significant differences at level $(P=.05)$ attributed to the variable of gender definitely in social domain, where females were mostly affected than males in English language speaking skill.
\end{abstract}

Keywords: Dialogue; speaking skill; problems; Universities. 


\section{INTRODUCTION}

When we talk about English Language (EL), it seems to be that we are talking about the major window by which we get the whole view of the world since it is the first language used in most areas of life. One of the most important skill of this language that leads to effective communication between people is speaking skill. Bygate [1] argues: that "Speaking skill is the ability in using oral language to explore ideas, intentions, thoughts and feelings to other people as a way to make the message clearly delivered and well understood by the listeners.

Khamkhien [2] believed that speaking skill is the most important in a second language.

So; most people who learn English Language have in their minds that they like to master the goal of developing the proficiency in speaking skill though it is a difficult task.

Celce-Murcia and Olshtain [3] pointed out that in some ways speaking can be considered the most difficult skill to acquire as it requires command of speech production sub-skills like vocabulary retrieval, choice of grammatical patterns, and sociocultural competence.

The linguists tried to find an appropriate method for teaching English Language according to the importance of skills from their Perspectives.

The views of those who interested in methods of teaching a language were various. For example, in grammar translation method, the concentration was on reading and writing skills whereas, in Direct method the focus is on speaking and listening. The supporters of each method believed that the skills were vary according to their importance. Anyhow, they all agreed that any skill is developed through practice, that is (read to read, speak to speak.....etc).

Wongsuwana [4] believed that speaking skill can be trained and it does not depend on the talent.

The linguists and experts of languages wrote many articles and books pertaining the difficulties of learning foreign languages in general and speaking skill in particular. In Jordan, the students start learning the skills of English Language from the first year of school (grade 1) extending to the last year of school (grade 12).

From my experience as a teacher of English Language for thirty years in the Ministry of
Education in Jordan, I noticed that the students in general do not have the desire to study English Language and this could be clear on the days of the General Secondary Exam of English Language. This may refer to factors that students suffer from.

Mueen [5] stated that there are several factors which affect students' performance in speaking English fluently; such as, lack of adequate and appropriate vocabulary, shyness, nervous, fearful to speak, and lack of confidence. Harry [6] stated that "anxiety and depression are just two effective factors that contribute to learning difficulties or are the result of learning difficulties. The impact of persistent failure can adversely affect a pupil's self-esteem, confidence, perceived self-efficacy, attitude and motivation. When confronted by certain tasks pupils may develop anxious feelings, fearing they will fail."

Biber [7] believed that some academic speaking skills such as giving an oral presentation or participating in classroom discussion require a much broader range of vocabulary knowledge, grammatical sophistication and discourse competence than is the case with typical daily life conversation.

Brown [8] listed six possible task categories for the classroom speaking performance as follows:

1. Imitative 2. Intensive 3. Responsive 4. Transactional (dialogue) 5. Interpersonal (dialogue) 6. Extensive (monologue).

Ur [9] stated the factors that affect speaking skill as follows:

1. "Inhibition. Students are worried about making mistakes, fearful of criticism, or simply shy.

2. Nothing to say. Students have no motive to express themselves.

3. Low or uneven participation. Only one participant can talk at a time because of large classes and the tendency of some learners to dominate, while others speak very little or not at all.

4. Mother-tongue use. Learners who share the same mother tongue tend to use it because it is easier and because learners feel less exposed if they are speaking their mother tongue."

The study aims at investigating the problems that students encounter in speaking skill through answering the following question: 
1- What are the problems that the students of southern region universities in Jordan encounter in English Language speaking skill from their perspectives?

2- Are there any statistically significant differences attributed to the variables of university, gender, and the academic level of the student and the interaction between the variables?

The study is limited to the students of faculties of art/ English Language specialization in the three public universities (Mu'ta, Al-Husein Bin Talal, and Tafila Technical University). The result generalization will be limited upon the subjectivity and precise of the responses of the sample and the psychometric of the instruments measurement.

\section{RELATED LITERATURE}

Researchers, linguists, experts, and those who interest in languages conducted many articles and wrote many books pertaining languages learning in general and speaking skill in particular and the difficulties encounter learners in a foreign language. Unfortunately; the problem is still available.

Goddard [10] indicated in his study that the environment and the personal characteristics of learners play an important role in their academic success. The school personnel, members of the families and communities provide help and support to students for the quality of their academic performance. This social assistance has a crucial role for the accomplishment of performance goals of students at school.

Dil [11] in his study reported that anxiety and unwillingness during the English speaking process are considered two of the biggest obstacles for EFL learners. Anxiety and unwillingness are caused by the fear of being negatively evaluated when making mistakes, particularly in front of their friends. It also revealed that students who perceive their English as "poor" feel more anxious and are more unwilling to communicate in English classes than the other students perceiving their English level as "very good, good, and OK."

Hamad [12] in the findings of her study indicated some factors that affect students' speaking skill such as, using Arabic Language in class, students fear of speaking English Language in public, instructors do not use strategies that develop speaking as role-play and debates.

Adayleh [13] in her study indicated that: "The problem is mainly reported in issues like sound recognition, connected speech, and the relation between spelling and sounds. This is clearly noticed when examining their performance in English. For example, they fail to assign stress properly and reflect content by intonation. They may even change sound quality. Mistakes in pronunciation that hinder meaning or change it are classified as bad pronunciation".

"Teaching strategies also contribute to this problem as they are inadequate, and they do not put emphasis on speaking, which results in a meager development of this skill. Besides, vocabulary items are taught in isolation, and listening materials are not used by the majority of school teachers because of the large number of teachers compared with the number of cassettes available. Teacher-training programs were found to be not very successful in changing the teachers' methodology" [14].

Aftat [15] believes that motivation is a product of good teaching. In his further explanation, He emphasizes that to motivate students to learn well and actively communicate in English, teachers should have passion, creativity and interest in their students. In other words, students motivation is really influenced by the teachers teaching performance. Therefore, it is important that teachers also show enthusiasm in their teaching performance.

Fahad [16] indicated that: "Saudi students find it inappropriate to speak in class because of their fear to be seen as verbally challenging their teachers' views openly and publicly. Even when they do, they speak a little. This leads to frustration on the side of the teacher, in addition to the absence of any clear feedback from the students: whether they have understood the lecture or not".

Lin I. [17] conducted a study choosing (213) university students as a sample for his study. The results indicated the problems that students encounter in speaking skill. The most common problem was mental representation. Other problems were, recognizing the sounds or words they read or hear, interpreting the intended word meanings, grasping main ideas, understanding metaphor, idioms or slang, identifying sentence structure. 
Mahdi [18] concluded in his qualitative study that the problems of speaking skill that students encounter are, lack of practice, lack of confidence, anxiety, and shyness. The results also indicated that most students desire to learn how to speak English well and are willing to interact with others in English Language in the classroom.

\section{STATEMENT OF PROBLEM}

For the increased need of using English Language in different areas of life, it becomes necessary for every person to be able to communicate with other persons outside his country using (EL). Through my teaching EL in Jordanian Ministry of Education for thirty years and instructor of EL in different universities, I noticed that students suffer from using English Language fluently and accurately which indicates that there are problems which hinder them from mastering English Language skills in general and speaking skill in particular.

\section{RATIONALE OF THE STUDY}

The results of the study could be beneficial for the instructors of universities, teachers at schools, students, parents, and local communities, to find solutions for the problems that the students encounter in English Language speaking skill.

\section{LIMITATIONS}

The results of the study could be limited by the following:

1- The study was conducted in the second semester of the academic year 2015-2016.

2- The sample of the study consisted of students of Mu'ta University, Al-Husein Bin Talal University, and Tafila Technical University in the southern region of Jordan.

3- The results are limited According to psychometric characteristics of the study tools and the study sample validity in in answering the items of the questionnaire.

\section{METHODOLOGY}

\subsection{Population and Sampling}

The population of the study consists of the students of faculties of arts in the three state universities in southern region of Jordan as Table 1 shows:
Table 1. Population of the study

\begin{tabular}{llll}
\hline University & Male & Female & Total \\
\hline Mu'ta University & 115 & 291 & 406 \\
Al-Husein Bin Talal & 106 & 278 & 384 \\
University & & & \\
Tafila Technical University & 97 & 174 & 271 \\
Total & $\mathbf{3 1 8}$ & $\mathbf{7 4 3}$ & $\mathbf{1 0 6 1}$ \\
\hline
\end{tabular}

The sample of the study consisted of (239) students male and female which forms $(22 \%$ of the population). The sample was chosen randomly from the students of Art Faculties who are specialized in English Language in the three universities. The compulsory courses of English Language and the academic levels from the first year until the fourth year were also chosen randomly as Table 2 shows:

Table 2. The sample distribution according to university and gender

\begin{tabular}{llll}
\hline University & Male & Female & Total \\
\hline Mu'ta university & 23 & 71 & 94 \\
Al-Husein Bin Talal university & 24 & 55 & 79 \\
Tafila Technical university & 18 & 48 & 66 \\
Total & $\mathbf{6 5}$ & $\mathbf{1 7 4}$ & $\mathbf{2 3 9}$ \\
\hline
\end{tabular}

\subsection{Instrument}

After reviewing the related literature, the researcher developed an instrument consists of three parts. The first part includes personal information, whereas the second one includes 27 items divided into 4 domains (psychological, instructor, social, and linguistic domains). Every responder has to express the degree of his agreement for each item. The items were scaled.

According to Likert five point scale as follows (strongly agree 5 points, agree 4 points, neutral 3 points, disagree 2 points, strongly disagree 1 point). The following classification was adopted to express the degree of the effect (1-2.33 low, 2.34-3.67 mid, 3.68-5 high). The third part is for the notes of the responders.

\subsection{Validity of the Instrument}

The instrument was showed to a jury of experts and specialists in this area. After taking their notes, the instrument was modified and adopted as a final copy.

\subsection{Reliability of the Study}

Reliability was checked using internal consistency, which measures the correlation between items of the instrument using Cronbach a equation. Table 3 represents the findings. 
Table 3. Cronbach's alpha for the reliability of the study

\begin{tabular}{lll}
\hline Domain & $\begin{array}{l}\text { Cronbach's } \\
\text { alpha }\end{array}$ & $\begin{array}{l}\text { No. of } \\
\text { items }\end{array}$ \\
\hline Psychological domain & 0.759 & 8 \\
Instructor domain & 0.702 & 8 \\
Social domain & 0.724 & 5 \\
Linguistic domain & 0.803 & 6 \\
The whole instrument & 0.822 & 27 \\
\hline
\end{tabular}

\section{RESULTS AND DISCUSSION}

To answer the first question, (what are the problems that the students of southern region universities in Jordan encounter in English Language speaking skill from their perspectives?) means and standard deviations were used for the domains and items of the instrument as Table 4 shows.

The figures in Table 4 indicate that the problems relating to social aspects were with high effect on learning English speaking skill. The other problems relating to psychological, instructor, and linguistic domains were with mid effect in learning English speaking skill.

According to the items of social domain, it is clear that item (1) which states (lack of English language conversation at home) with a mean of (4.083) and item (3) which states (a criticism for who speaks English language from surrounding people) with a mean of (4.037), those two items were the most which cause problems for speaking skill in the social domain. These results agree with [10] study.

Regarding psychological domain, it was clear from the figure of item (6) which runs ( I feel with anxiety when I try to speak in English language) was that most important problem with a mean of (3.677) followed by the items of lack of motivation, feeling confused, lack of interesting, and feeling shy when using English language speaking. This result meets with $[11,15,12,18]$, studies.

For the domain of the instructor, item (6) which states (the teacher uses his native language during his speech with students) was the most effective problem in English language speaking skill. This meets with [12], study. The results of this study disagrees with [18] study regarding to the desire, or willingness of speaking English Language.

Finally, pertaining the linguistic domain, item (1) which states (I lack for vocabularies) and item (5) which runs (I feel weak in English language grammar), were the important problems in
English language speaking. The results agree with [13] and [17] studies.

For answering question number two (Are there statistically significant differences attributed to the variables of university, gender, and the academic level (MANOVA) was used as Table 5 shows.

The results indicated that there are statistically significant differences to the variable of university for all the domains of speaking problems those differences were in favor of Tafila Technical University.

The figures show that there are statistically significant differences at level $(P=.05)$ attributed to the variable of gender definitely in social domain, where females were most affected than males in English language speaking.

According to the academic level, it is obvious that there are statistically significant differences at level $(P=.05)$ which indicate that levels the students of third and fourth year were most affected in social domain when compared with first and second year levels.

Regarding the interaction between the variables, it is found that there is an effect for the interaction between the university and the gender of students in social domain.

There is also an effect for the interaction between the university, gender, and academic level in psychological domain for English language speaking skill.

The results of the study indicated that the students' learning speaking skill is affected by the following: social psychological, instructor, and linguistic problems arranged successively. It is clear that the social problems are the most effective ones and this could be due to the students mother language which is Arabic language and it is the means of communication between the members of the family and society as well. So; it seems to be surprising to find a person who speaks English and if that happens it will be ridicule and censure from others, so that; the goal of English speaking skill is just in learning which takes place inside the classroom for the purposes of evaluation and tests. The social problems reflected their effects on psychological problems where learning and practicing speaking motivation were descended in addition to feeling with shy, anxiety, lack of self-confidence, and the fear from making errors while speaking which lead to weak learning of speaking skill. 
Table 4. Means and standard deviations for the domains and items of the instrument

\begin{tabular}{|c|c|c|c|c|c|}
\hline Domain & No. & Item & Mean & $\begin{array}{l}\text { Standard } \\
\text { deviation }\end{array}$ & $\begin{array}{l}\text { Degree of } \\
\text { effect }\end{array}$ \\
\hline Psychological & 1 & I lack for interesting in English speaking skill & 3.313 & 1.252 & mid \\
\hline \multirow[t]{8}{*}{ domain } & 2 & I lack for wish in English speaking skill & 2.979 & 1.227 & mid \\
\hline & 3 & I feel shy when I speak in English language & 3.054 & 1.328 & mid \\
\hline & 4 & I feel confused when I speak in English language & 3.489 & 1.215 & mid \\
\hline & 5 & I lack for motivation to speak in English language & 3.497 & 1.184 & mid \\
\hline & 6 & I feel with anxiety when I try to speak in English language & 3.677 & 1.199 & mid \\
\hline & 7 & I hesitate when I try to speak English language to avoid making errors & 3.050 & 1.235 & mid \\
\hline & 8 & I lack for confidence when I try to speak English language & 3.251 & 1.248 & mid \\
\hline & Average & & 3.489 & 0.665 & mid \\
\hline Instructor & 1 & The teacher listens carefully to the students speech to understand their errors & 3.636 & 1.176 & mid \\
\hline \multirow[t]{8}{*}{ domain } & 2 & The teacher understands the language skills well & 3.205 & 1.245 & mid \\
\hline & 3 & The teachers' speech is appropriate to the level of students & 3.698 & 1.100 & high \\
\hline & 4 & The teacher tolerates the students' errors & 3.497 & 1.208 & mid \\
\hline & 5 & The teacher reinforce the students when they speak in English language & 3.313 & 1.102 & mid \\
\hline & 6 & The teacher uses his native language during his speech with students & 3.171 & 1.155 & mid \\
\hline & 7 & $\begin{array}{l}\text { The teacher applies the way of pairs and groups for his students in speaking } \\
\text { English language }\end{array}$ & 3.343 & 1.166 & mid \\
\hline & 8 & The teacher varies his methods in teaching English speaking skill & 4.050 & 1.183 & High \\
\hline & Average & & 3.489 & 0.665 & mid \\
\hline \multirow[t]{6}{*}{ Social domain } & 1 & Lack of English language conversation at home & 4.083 & 1.093 & high \\
\hline & 2 & Lack of English language conversation at home & 3.661 & 1.222 & mid \\
\hline & 3 & A criticism for who speaks English language from surrounding people & 4.037 & 1.127 & high \\
\hline & 4 & Lack of opportunities in meeting native speakers of English language & 3.899 & 1.155 & Mid \\
\hline & 5 & $\begin{array}{l}\text { Lack of holding course from local society associations in English language } \\
\text { speaking skill }\end{array}$ & 3.581 & 1.141 & mid \\
\hline & Average & & 3.852 & 0.708 & high \\
\hline Linguistic & 1 & I lack for vocabularies & 3.468 & 1.169 & mid \\
\hline \multirow{6}{*}{ domain } & 2 & I feel weak in constructing sentences & 3.280 & 1.202 & mid \\
\hline & 3 & I feel weak in correct pronunciation & 3.276 & 1.276 & mid \\
\hline & 4 & $\begin{array}{l}\text { It is difficult for me to comprehend the accent of the native speaker of English } \\
\text { language }\end{array}$ & 3.259 & 1.334 & mid \\
\hline & 5 & I feel weak in English language grammar & 3.359 & 1.275 & mid \\
\hline & 6 & $\begin{array}{l}\text { I feel weak in understanding the expressions and concepts of English } \\
\text { language }\end{array}$ & 2.552 & 1.266 & mid \\
\hline & Average & & 3.199 & 0.891 & mid \\
\hline
\end{tabular}


Al-Roud; BJESBS, 18(3): 1-9, 2016; Article no.BJESBS.28404

Table 5. Tests of between- subjects effects

\begin{tabular}{|c|c|c|c|c|c|c|}
\hline Source & Dependent variable & Type III sum of squares & df & Means square & $\mathbf{F}$ & Sig. \\
\hline \multirow[t]{5}{*}{ University } & Psychological domain & 5.020 & 2 & 2.510 & 6.106 & .003 \\
\hline & Instructor domain & 5.020 & 2 & 2.510 & 6.106 & .003 \\
\hline & Social domain & 4.149 & 2 & 3.574 & 8.020 & .000 \\
\hline & Linguistic domain & 5.169 & 2 & 2.584 & 3.405 & .035 \\
\hline & average total & 5.408 & 2 & 2.704 & 11.980 & .000 \\
\hline \multirow[t]{5}{*}{ gender } & Psychological domain & .199 & 1 & .199 & .484 & .487 \\
\hline & Instructor domain & .199 & 1 & .199 & .484 & .487 \\
\hline & Social domain & 2.303 & 1 & 2.303 & 5.167 & .024 \\
\hline & Linguistic domain & .039 & 1 & .038 & .049 & .824 \\
\hline & average total & 1.030 & 1 & 1.030 & 4.564 & .034 \\
\hline \multirow[t]{5}{*}{ Level } & Psychological domain & .300 & 1 & .300 & .731 & .394 \\
\hline & Instructor domain & .300 & 1 & .300 & .731 & .394 \\
\hline & Social domain & 3.311 & 1 & 3.311 & 7.428 & .007 \\
\hline & Linguistic domain & .557 & 1 & .557 & .733 & .393 \\
\hline & average total & .357 & 1 & .357 & 1.580 & .210 \\
\hline \multirow[t]{5}{*}{ University * gender } & Psychological domain & 1.106 & 2 & .553 & 1.345 & .263 \\
\hline & Instructor domain & 1.106 & 2 & .553 & 1.345 & .263 \\
\hline & Social domain & 2.878 & 2 & 1.439 & 3.229 & .041 \\
\hline & Linguistic domain & .038 & 2 & .019 & .025 & .975 \\
\hline & average total & .484 & 2 & .242 & 1.071 & .344 \\
\hline \multirow[t]{5}{*}{ University * level } & Psychological domain & .113 & 2 & .057 & .137 & .872 \\
\hline & Instructor domain & .113 & 2 & .057 & .137 & .872 \\
\hline & Social domain & .774 & 2 & .387 & .869 & .421 \\
\hline & Linguistic domain & 3.738 & 2 & 1.869 & 2.462 & .088 \\
\hline & average total & .404 & 2 & .202 & .896 & .410 \\
\hline \multirow[t]{5}{*}{ gender* level } & Psychological domain & .085 & 1 & .085 & .206 & .650 \\
\hline & Instructor domain & .085 & 1 & .085 & .206 & .650 \\
\hline & Social domain & 1.033 & 1 & .1033 & 2.317 & .129 \\
\hline & Linguistic domain & .178 & 1 & .178 & .235 & .628 \\
\hline & average total & .445 & 1 & .445 & 1.970 & .162 \\
\hline \multirow[t]{5}{*}{ University * gender * level } & Psychological domain & 3.030 & 2 & 1.515 & 3.686 & .027 \\
\hline & Instructor domain & 3.030 & 2 & 1.515 & 3.686 & .027 \\
\hline & Social domain & .196 & 2 & .098 & .220 & .802 \\
\hline & Linguistic domain & .536 & 2 & .268 & .353 & .703 \\
\hline & average total & .027 & 2 & .014 & .060 & .942 \\
\hline
\end{tabular}


Regarding to the instructor, it is clear that most of them concentrate on teaching grammar, reading, writing more than teaching speaking. They also use the native language (Arabic language) which impedes learning speaking skill. In addition to what Mentioned, the difficulty that teacher encounter in evaluating speaking skill. Learning speaking skill is affected with linguistic skills, so the lack of vocabularies that the students possess and the weakness of mastering language grammar cause a defect in learning speaking skill. The reason for that is, teachers of English Language teach vocabulary in isolation not in situations

\section{CONCLUSION}

The results of the study indicated that the students of the three universities were suffering from many problems in possessing English Language speaking skill, definitely those relating to social, psychological, and the instructor domains, in addition to linguistic domain.

It also concluded that the student, teacher and instructor, parents, and community are responsible for the weakness of students in English speaking skill, and they have to work together in order to solve the problems that students encounter. However attention should be given for female students since they face many obstacles in possessing speaking skill by encouraging and motivating them to participate in learning English speaking skill.

\section{RECOMMENDATIONS}

1. Instuctors should cocentrate on speaking skillas well as other skills.

1- Students should practice speaking skill regardless the critisizm, shy, unwellingness, and anxiety they may face.

2. The decision makers in Ministry of Education should give additional care in speaking skill at schools.

3. Courses in English speaking skill should be held for students at schools and even at universities.

4. Teachers should not use Arabic language for a long time in the classroom.

\section{COMPETING INTERESTS}

Author has declared that no competing interests exist.

\section{REFERENCES}

1. Bygate M. Speaking. Oxford: Oxford University Press.

2. Khamkhien A. Teaching English speaking and English speaking tests in the Thai context: A reflection from thai perspectives. English Language Journal. 2010;3(1):184200.

3. Celce-Murcia M, Olshtain E. Discourse and context in language teaching. Cambridge: Cambridge University Press; 2000.

4. Wongsuwana. Could be trained. Thailand Education Journal. 2006;21:44-50.

5. Mueen A. English language teaching in Pakistan. Islamabad: The PFI Publication; 2000.

6. Harry A. An A to $Z$ practical guide to learning difficulties. David Fulton Publishers, New York; 2006.

7. Biber D. Discourse on the move: Using corpus analysis to describe discourse structure. Amesterdam: John Benjamins; 2007.

8. Brown H. Teaching by principles: An interactive approach to language pedagogy. White Plains, NY: Longman; 2001.

9. Ur P. A course in language teaching. Cambridge: Cambridge University Press; 1996.

10. Goddard R. Relational networks, social trust, and norms: A social capital perspective on students' chances of academic success. Educational Evaluation \& Policy Analysis. 2003;25:59-74.

11. Dil Y. EFL learners' communication obstacles. Journal of Social Sciences. 2009;8(29):84-100.

12. Hamad M. Factors negatively affect speaking skills at Saudi colleges for girls in the south. English Language Teaching. 2013;6(12):77-97.

13. Adayleh $\mathrm{H}$. The difficulties faced by English language students at Mu'tah University in mastering English language pronunciation. European Journal of Social Sciences. 2013;38(2):205-209.

14. Rabab'ah G. Communication problems facing Arab learners of English. Journal of Language and Learning. 2005;3(1):37-52.

15. Aftat M. Motivation and genuine learning; 2008.

Available:http://www.englishteacher1.com/ motivation.htm

(Retrieved March, 2013) 
16. Fahad H. Developing Saudi EFL students' oral skills: An integrative approach. English Language Teaching. 2011;4(3):84-89.

17. Lin L. Chinese-speaking learners cognitive comprehension problems with English video-based materials. Journal of
Educational Computing Research. 2014;51(1):23-47.

18. Mahdi D. Strategies and techniques for fostering oral communication confidence in EFL students. Arab World English Journal. 2015;6(2):162-173.

(C) 2016 Al-Roud; This is an Open Access article distributed under the terms of the Creative Commons Attribution License (http://creativecommons.org/licenses/by/4.0), which permits unrestricted use, distribution, and reproduction in any medium, provided the original work is properly cited.

Peer-review history:

The peer review history for this paper can be accessed here:

http://sciencedomain.org/review-history/16679 